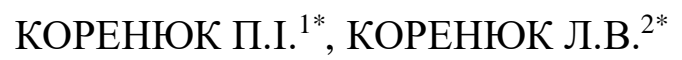

1* д.е.н., професор, завідувач кафедри менеджменту організацій і адміністрування Дніпровського державного технічного університету, e-mail: korenyukp@ gmail.com, ORCID ID: 0000-0001-8321-3199

2* к.е.н., доцент кафедри фінансів та економічної безпеки Дніпровського національного університету імені В. Лазаряна, e-mail: lusikorenyuk@gmail.com, ORCID ID: 0000-0003-3187-3288

\title{
ВПЛИВ ЗАРОБІТНОї ПЛАТИ НА РІВЕНЬ БЕЗРОБІТТЯ В КОНТЕКСТІ СОЦІАЛЬНОЇ ВІДПОВІДАЛЬНОСТІ РОБОТОДАВЦІВ
}

\begin{abstract}
Мета. Робота присвячена проведенню аналізу впливу заробітної плати на рівень безробіття в контексті соціальної відповідальності роботодавців та конкретизація заходів щодо зниження безробіття. Методика. Для вирішення даної наукової проблематики застосовано: структурний метод; порівняльного аналізу емпіричних даних; абстрактно-логічного узагальнення. Результати. У роботі проаналізовано вплив заробітної плати на рівень безробіття в контексті соціальної відповідальності роботодавців. На основі аналізу визначено резерви щодо зниження безробіття та поліпшення соціальних стандартів життя населення через підвищення рівня його заробітної плати. Вказано на пріоритетні напрямки його перетворення в ефективний інструмент соціально-економічного розвитку промислового регіону. Наукова новизна. У процесі аналізу впливу заробітної плати на рівень безробіття в контексті соціальної відповідальності роботодавців висновки та пропозиції здійснені під призмою специфіки Дніпропетровської області як промислового регіону. Практична значимість. Окремі результати та висновки статті можуть бути використані органами місцевої влади та місцевого самоврядування промислових областей.
\end{abstract}

Ключові слова: заробітна, плата, безробіття, соціальна, відповідальність, соціальні, робоча, стандарти, сила

\section{Постанова проблеми}

В умовах сталого розвитку ринок праці $\epsilon$ складним та динамічним складовим елементом національної економіки. Ринок праці, як показує світовий досвід, безпосередньо впливає на проблеми безробіття, рівень оплати праці та міграцію населення. За своєю сутністю соціальна відповідальність функціонує у якості соціального інституту, який $є$ раціональним та людиноорієнтованим. Саме тому є актуальним дослідження впливу заробітної плати на показники та рівень безробіття соціальної відповідальності роботодавців.

\section{Аналіз останніх досліджень і публікацій.}

Проблеми комплексного дослідження впливу заробітної плати на рівень безробіття під призмою соціальної відповідальності досліджені в працях ряду видатних українських вчених таких як Д. П. Богиня [1], Л. Д. Гармидер [2], Л. А. Гончар [2], А.Г. Горілий [3], О.А. Заклекта [4], О. А. Єрмоленко [5], В.Капітан [6], С. Кулицький [7], І. Б. Круп'як [8], Л. Б. Круп'як [8], О. Пазюк [9], О. Пономарьова [9], Л. М. Федоришина [10] та інших.

\section{Формулювання цілей статті}

Робота присвячена аналізу впливу заробітної плати на рівень безробіття в контексті соціальної відповідальності роботодавців та конкретизація заходів щодо зниження безробіття в сучасних умовах.

\section{Виклад основного матеріалу дослідження}

Характерними

особливостями трансформації сучасних економічних процесів в умовах сталого розвитку в Україні $\epsilon$ стабілізація та структурна перебудова. Структурні перетворення в національній економіці змінили відносини зайнятості населення, інтенсифікували процес руху робочої сили, висвітлили нові актуальні проблеми на ринку праці, становлення якого супроводжується посиленням його сегментації. Ринок праці є не лише структурним елементом національної економіки, що формує її трудовий потенціал, а й багатогранною сферою суспільного життя, яка визначає ступінь ефективності функціонування економічної системи держави. В той же час, суттєвим недоліком розвитку ринку праці в Україні 3 позиції соціальної відповідальності є низький 
рівень iі оплати не лише в порівнянні із значенням даного показника у країнах 3 розвиненою економікою, а й 3 урахуванням фактичної продуктивності праці. Такий компонент саморегуляції ринку праці, як заробітна плата, не приведена у відповідність із вартістю робочої сили і деформує попит i пропозицію [6].

Основними чинниками безробіття в Україні на сьогоднішній день $\epsilon$ : низький рівень заробітної плати, яку пропонують роботодавці; невідповідність системи підготовки фахівців потребам ринку праці; система освіти, що повільно реагує на зміни ринку; відсутність сприятливих умов для малого та середнього бізнесу; недостатньо потужні важелі стимулювання розвитку виробничої i соціальної інфраструктури та створення нових робочих місць в малому бізнесі. Крім того, світова фінансова криза позначилася не лише на малих підприємствах, але i на великих галузевих комплексах.

3 огляду на нинішню ситуацію, в якій знаходиться країна, безробіття $\epsilon$ гострою проблемою, 3 якою стикається населення України в умовах сьогодення. Причиною цього $\epsilon$ неефективність використання робочої сили у минулому і відсутність економічних умов, які б дали змогу людям застосовувати свої навички у продуктивній роботі за гідну плату, війна на сході країни.

Саме тому це явище 3 позиції соціальної відповідальності $\epsilon$ як економічною, так i соціальною проблемою. Безробіття у нашій країні набуло масового характеру i несе реальну загрозу для державного та суспільного благополуччя. Українські реалії, на жаль, полягають в тому, що соціальна відповідальність в суспільстві так і не стала домінантним чинником регулювання суспільного життя.

За даними Державної служби статистики України, рівень безробіття склав $10,5 \%$ за підсумком першого кварталу 2021 року, що $\epsilon$ найвищим показником з початку 2017 року. Кількість безробітних у віці від 15 років і старше і у віці 15-70 років зросла до 1,8 млн осіб, уточнюють в Держкомстаті. Рівень зайнятості населення у віці $15-70$ років становить 55\%. Всього, кількість зайнятих у віці 15-70 років становить 15,4 млн осіб.

Мінімальну заробітну плату в Україні традиційно розглядали як один із соціальних стандартів, а не як інструмент політики на ринку праці, що, серед іншого, покращує ринкові позиції працівників 3 низькою заробітною платою. Розмір заробітної плати фіксований показник, який визначається в Законі про Державний бюджет на відповідний рік і нижче якого зарплата працівника не може опускатися, якщо він повністю виконав місячну норму праці, відповідно до Закону України «Про оплату праці» та Кодексу законів про працю України.

Таблиця 1

Рівень безробіття в Україні з 2015 по 2021 рр., тис. чол. Джерело: Розроблено за даними Державного Комітету статистики Украӥни

\begin{tabular}{|c|c|c|c|c|c|c|}
\hline & $\begin{array}{c}\text { Всього } \\
\text { населення }\end{array}$ & $\begin{array}{c}\text { Економічна } \\
\text { активність } \\
\text { населення }\end{array}$ & $\begin{array}{c}\text { Заняте } \\
\text { населення }\end{array}$ & $\begin{array}{c}\text { Безробітнє } \\
\text { населення }\end{array}$ & $\begin{array}{c}\text { Рівень } \\
\text { безробіття }\end{array}$ & $\begin{array}{c}\text { Зареєстрова-но } \\
\text { безробітніх }\end{array}$ \\
\hline 2015 & 42760,5 & 17396,0 & 15742,0 & 1654,0 & $9,5 \%$ & 461,1 \\
\hline 2016 & 42584,5 & 17303,6 & 15626,1 & 1677,5 & $9,7 \%$ & 407,2 \\
\hline 2017 & 42386,4 & 17193,2 & 15495,9 & 1697,3 & $9,9 \%$ & 352,5 \\
\hline 2018 & 42153,2 & 17296,2 & 15718,6 & 1577,6 & $9,1 \%$ & 341,7 \\
\hline 2019 & 41902,4 & 17381,8 & 15894,9 & 1486,9 & $8,6 \%$ & 338,2 \\
\hline 2020 & 41588,4 & 16917,8 & 15244,5 & 1673,3 & $9,9 \%$ & 459,2 \\
\hline 2021 & 41488,0 & 16617,2 & 14813,7 & 1803,5 & $10,9 \%$ & 449,7 \\
\hline
\end{tabular}

На початку 2000x років були спроби декілька разів визначати орієнтовний розмір мінімальної заробітної плати на основі тристоронніх домовленостей у Генеральній угоді між урядом, роботодавцями та профспілками. Причому, всі ці спроби були вдалі. Але врешті решт мінімальна заробітна плата стала передусім заручником фіскальних можливостей уряду, але це при тому, що бажані 
рівні мінімальної заробітної плати профспілок та роботодавців різнились.

Мінімальна заробітна плата $\epsilon$ одним 3 потужних інструментів впливу на національну економіку, зокрема на іiі соціальну складову. Наприклад, як показує досвід тієї ж Польщі (табл. 3 по тексту), підвищення мінімальної заробітної плати в контексті соціальної відповідальності, сприяє зростанню величини макроекономічних показників, зокрема ВВП, у абсолютному та відносному виразі. Причому досвід свідчить, що приватний сектор поступово адаптує заробітні плати 3 урахуванням підвищення мінімальної заробітної плати у випадку ії підвищення. В Україні проводиться стала політика щодо зростання мінімальної заробітної плати у контексті соціальної відповідальності роботодавців (табл. 2).

Таблиця 2

Мінімальна заробітна плата в Україні з 2015 по 2021 рp.

Джерело: Розроблено за даними Державного Комітету статистики Украӥни

\begin{tabular}{|c|c|}
\hline Період & Місячна \\
\hline з 01.01.2015 по 31.08.2015 & 1218 грн \\
\hline з 01.09.2015 по 31.12.2015 & 1378 грн \\
\hline з 01.01.2016 по 30.04.2016 & 1378 грн \\
\hline з 01.05.2016 по 30.11.2016 & 1450 грн \\
\hline з 01.12.2016 по 31.12 .2016 & 1600 грн \\
\hline з 01.01.2017 по 31.12.2017 & 3200 грн \\
\hline з 01.01.2018 по 31.12.2018 & 3723 грн \\
\hline з 01.01.2019 по 31.12.2019 & 4173 грн \\
\hline з 01.01.2020 по 31.08.2020 & 4723 грн \\
\hline з 01.09.2020 по 31.12.2020 & 5000 грн \\
\hline з 01.01.2021 по 30.11.2021 & 6000 грн \\
\hline 301.12 .2021 & 6500 грн \\
\hline
\end{tabular}

В реальній практиці має місце наявність вибору Уряду між політикою підвищення мінімальної заробітної плати та стимулюванням робочих місць. Так, в цілому, мінімальна заробітна плата (відповідно до міжнародної організації праці) покликана знизити бідність серед працюючих (тому існує такий термін як working poor). Вона може посилити позицію низькокваліфікованих працівників на ринку праці, оскільки роботодавці змушені сплачувати заробітну плату не нижчу, за мінімальну. Разом 3 тим, стрімке підвищення мінімальної заробітної плати може призвести до скорочення передусім саме некваліфікованих працівників.

Оцінка впливу підвищення заробітної плати на безробіття в національній економіці $\epsilon$ складною 3 огляду на наявність великого тіньового сектору, поведінку якого прогнозувати не просто вкрай складно, але подеколи і неможливо. В цілому попередній досвід вітчизняних стейкхолдерів в Україні свідчить про наявність досить великого набору інструментарію для сприяння підвищенню соціальних стандартів життя працівників.

Але це $\epsilon$ складним питанням. Так, як стверджують фахівці 3 американського Національного бюро економічних досліджень, які досить детально вивчили досвід 14 країн і дійшли обгрунтованого висновку, що підвищення мінімальної заробітної плати лише на 4 - 5 доларів США призводить до скорочення робочих місць на підприємстві на 2 відсотки [11].

3 одного боку це і справді виглядає таким чином, але 3 іншого, то спостерігається інша 
досить цікава тенденція. Якщо у 2017 році в Україні рівень безробіття був 10 відсотків, то у 2 кварталі 2018 року він склав 8,3 відсотки, тобто скоротився на 1,7 одиниці. В цей же час за даними таблиці 2 мінімальна заробітна плата зрослі з 3200 грн на місяць у 2017 році до 3723 грн у 2018 році.

На сучасному етапі суспільного розвитку фактичний експорт робочої сили став одним 3 важливих напрямів функціонування української економіки. Вітчизняні стейкхолдери мають зрозуміти, що в маштабному виразі відбувається процес не просто відтоку робочої сисли за кордон, але виїзжає частина генофонду нації. Як правило, виїзжають конкурентноздатні на європейському ринку фахівці. В Україні спостерігається парадоксальна тенденція. 3 одного боку, на фоні дальшого розвитку суверенітету, ми бачимо, що переважна кількість громадян намагається брати відповідальність лише за власні дії. А з іншого боку, зростає векторність передачі відповідальності за зміну соціальних умов життєдіяльності на державу. Відповідним чинником, поступають і наші стейкхолдери. I, як наслідок, Державний комітет статистики України фіксує 11 країн, куди українці їздять на заробітки найчастіше. Лідерами імпорту дешевої кваліфікованої робочої сили з України $\epsilon$ Польща, Росія, Італія, Чехія та США. Вичерпної і абсолютно достовірної інформації про те, скільки ж українців їздить працювати за кордон, немає. Залишається спиратися на дані Державної служби статистики, які свідчать, що за досліджуваний період на заробітках перебувало 1 млн 303 тисячі українців. У 2019 році чинний міністр соціальної політики України повідомив, що, за експертними оцінками, на постійній основі за кордоном працює 3,2 млн громадян України, а в окремі періоди - від 7 до 9 млн осіб. Так, за підрахунками Нацбанку, у 2019 році трудові мігранти переказали в Україну 12 мільярдів доларів США, а це $\epsilon$ понад 8 \% ВВП країни. Минулого 2020 року через карантинні обмеження та закритість кордонів перекази в Україну від заробітчан склали біля 10 млрд доларів, що складає 83,3 іфдсотки від попередного року.

Чи не найбільшим імпортером української робочої сили став ринок праці сусідньої Польщі. Те, що саме Польща стала провідним реципієнтом українських трудових мігрантів серед країн світу, є цілком закономірним й обумовлено такими причинами. Наприклад, близько двох мільйонів українців сьогодні працюють у Польщі, а деякі експерти стверджують, що ця цифра у рази більша, адже значна частина людей їде нелегально i на нетривалий час.

Ситуації в різних країнах є досить різними. Щодо Польщі, то завдяки фаховим діям уряду, країні вдалося увійти в список держав 3 одним iз найнижчих рівнів безробіття. Рівень безробіття визначає поточний стан економіки в країні. Згідно з сучасними критеріями, рівень безробіття в 4-5\% вважається нормою, низьке безробіття у 2-4\% вказує на період підйому, а понад 7 відсотків, говорить про наявність темпів спаду економіки. При цьому, середня заробітна плата в Польщі постійно зростає. Основні показники можна відстежити в таблиці порівняння нижче (табл. 3).

Центральне статистичне управління Польщі надало інформацію, що у грудні 2020 року середня заробітна плата за місяць стала на $6,8 \%$ вище, ніж в листопаді 2020 і на 4,3\% вище, ніж в грудні 2019 року. У 2019 Польща була на четвертому місці, з безробіттям на рівні $3,3 \%$, а в серпні 2020 року, рівень безробіття склав всього 3,1\%. Опубліковані Євростатом дані свідчать про позитивну ситуацію на ринку праці. Так, за оцінками Нацбанку Польщі, українські кадри забезпечують 0,3-0,9\% зростання ВВП країни щороку. За підрахунками економістів 3 Національного банку Польщі (НБП), 11 \% зростання польського ВВП за 2014-2018 pp. - це заслуга саме працівників із-за кордону, здебільшого 3 України. Ситуація не зовсім сприятлива і якби не масовий потік на польський ринок праці іммігрантів з України, це зростання було би набагато меншим.

Зрозуміло, що причина, яка спонукає виїжджати українців за кордон $є$ більш високий рівень оплати праці. Так, Уряд Польщі 31 січня 2021 року також збільшив на 1 злотий (7,5 грн) погодинну оплату праці. Попри це, вона все ж залишатиметься утричі нижчою, ніж в сусідній Німеччині чи інших розвинутих країнах Західної Європи. Тим не менше, поки ці країни не відкриють свої ринки праці для українців, то Польща, ймовірно, ще довго залишатиметься основним напрямком трудової міграції українців. 3 іншого боку, доки національна економіка не генеруватиме достатньої кількості робочих місць праці та достатню заробітну 
плату у порівнянні 3 тією ж Польщею, щоб запропонувати працездатним кваліфікованим українцям аби ті в пошуках роботи менше оглядалися на сусідів. Але, на жаль нині
Україна, з огляду на значний людський ресурс, залишатиметься головним постачальником робочої сили для країн Свропи.

Таблиця 3.

Порівняння показників України та Полыщі за 2015-2020 р.p. [1],[2] Джерело: Розроблено за даними Державного Комітету статистики Украӥни

\begin{tabular}{|c|c|c|c|}
\hline Показник & Роки & Україна & Польща \\
\hline \multirow{5}{*}{ Середня заробітна плата, \$ } & 2015 & 213,8 & 1040,63 \\
\cline { 2 - 4 } & 2016 & 173,4 & 1063,58 \\
\cline { 2 - 4 } & 2017 & 221,5 & 1182,75 \\
\cline { 2 - 4 } & 2018 & 275,3 & 1359,81 \\
\cline { 2 - 4 } & 2019 & 332,3 & 1314,32 \\
\cline { 2 - 4 } & 2020 & 430,5 & 1427,6 \\
\hline \multirow{5}{*}{ ВВП на душу населення, \$ } & 2015 & 2115,4 & 12578,5 \\
\cline { 2 - 4 } & 2016 & 2185,9 & 12447,44 \\
\cline { 2 - 4 } & 2017 & 2640,3 & 13864,68 \\
\cline { 2 - 4 } & 2018 & 3095,2 & 15468,48 \\
\cline { 2 - 4 } & 2019 & 3659,8 & 15692,51 \\
\cline { 2 - 4 } кількості працездатного & 2020 & 3725,6 & 7,5 \\
\hline населення) & 2015 & 9,5 & 6,2 \\
\cline { 2 - 4 } & 2016 & 9,7 & 4,9 \\
\cline { 2 - 4 } & 2017 & 9,9 & 3,8 \\
\cline { 2 - 4 } & 2018 & 9,1 & 3,3 \\
\cline { 2 - 4 } & 2019 & 8,6 & 3,2 \\
\cline { 2 - 4 } & 2020 & 9,9 & \\
\hline
\end{tabular}

Доцільно відмітити наявність аргументів щодо того, чому підвищення мінімальної зарплати може бути корисним для національної економіки. Так, це добре для тих, хто отримує зарплату, що не дотягує навіть до прожиткового мінімуму. Крім того, це дозволить покрити дефіцит Пенсійного фонду, якщо не повністю, то хоча б частково. В той же час, такий крок держави має пожвавити споживчі процеси в національній економіці. Але, на думку експертів, ці позитивні наслідки можливі в разі підвищення рівня МЗП до 6500 гривень, на що $\epsilon$ і ресурси, і доцільність. Однак заявлені урядом наступні етапи підвищення рівня «мінімалки», на нащу думку, призведуть до погіршення ситуації як для бізнесу, так i громадян. I таких аргументів у експертів набагато більше.

Але в той же час, потрібно почати 3 того, що економічних підстав для збільшення мінімальної заробітної плати немає, бо включається цей механізм у разі зростання продуктивності праці «для компенсації розподілу створеного національного багатства серед найманих працівників». Якщо ж продуктивність праці не збільшується або збільшується несуттєво (а саме про це свідчать урядові макроекономічні показники), то таке втручання уряду в динаміку оплати праці створює низку ризиків та викривлень економічних стимулів, 3 якими Україні доведеться жити не один рік.

Окрім того, національна економіка структурована так, що частка інвестиційної складової набагато менша порівняно 3 часткою споживання. Темпи зростання реального ВВП у попередні роки i на найближчу перспективу становлять 3 відсотки на рік, тоді як приватне споживання (за період 2018-2019 років) збільшувалося в середньому на 10 відсотків за цей же період. В той час нинішні показники засвідчують, що спостерігається позитивна тенденція щодо зближення темпів росту реального ВВП та споживання. 


\section{Висновки}

Отже, проблема безробіття в контексті соціальної відповідальності $є$ ключовим питанням сьогодення у національній економіці i, якщо це не вирішувати, то неможливо налагодити ефективну діяльність економіки і рівень безробіття при цьому буде зростати. I, як наслідок економічних негараздів, як правило буде знижуватись заробітна плата. Держава може прямо впливати на величину мінімальної заробітної плати, але вона не може прямо вплинути на рівень заробітної плати в бізнесі. Одним 3 резервів цього впливу $\epsilon$ формування соціальної відподальності роботодавців, тобто формування топ-менеджменту та власників компаній і фірм 3 прогресивним соціально орієнтованим світоглядом. Як відомо, на забезпечення соціальних стандартів життя населення впливають всі види доходів населення. Отже, держава, опосередковано впливаючи через чинне законодавство на національну економіку, отримує резерви для зростання соціальних стандартів життя населення. Спостерігається певний неоднозначний вплив зростання мінімальної заробітної плани на рівень безробіття. Так, підвищення мінімальної заробітної плати має бути у відповідності 3 темпами зростання національної економіки 3 метою запобігання інфляційним процесам. В той же час, запровадження заходів щодо зниження безробіття дасть змогу поліпшити ситуацію зайнятості на національному ринку праці, що сприятиме забезпечення сталого розвитку держави.

На нашу думку, для зниження безробіття в Україні потрібно на державному рівні сприяти пожвавленню підприємництва та ділової активності населення. Вітчизняних роботодавців потрібно стимулювати зберігати робочі місця та проводити перепідготовку працівників та осіб, які втратили роботу. Потрібно, врешті; завершити пенсійну реформи та знизити пенсійне навантаження на виробничий сектор національної економіки. У контексті захисту інтелектуального потенціалу суспільства потрібно організовувати спеціальні ярмарки праці для навчальних закладів 3 метою працевлаштування випускників; розширювати досвід організації зустрічей із роботодавцями та колишніми безробітними, які успішно знайшли роботу чи заснували власний бізнес.

Створення сприятливого клімату для зростання соціальних стандартів життя населення через використання державою непрямого впливу дозволить знизити відток робочої сили за кордон. Потрібно посилити координацію міжнародної діяльності в частині інформаційного обміну 3 питань зайнятості; забезпечити стабільне фінансування та сталу державну підтримку розвитку підприємництва та виробничого сектору національної економіки. Лище цілеспрямоване активне підвищення рівня зайнятості населення на діючих $\mathrm{i}$ на новостворених високоефективних робочих місцях в контексті посилення соціальної відповідальності стейкхолдерів допоможе вивести національну економіку 3 складного стану і поставить їі на шлях сталого розвитку. I як наслідок, мають зрости соціальні стандарти життєдіяльності населення i 3'явиться реальний простір для сталого розвитку ринкових і соціальних перспектив.

\section{KORENYUK P.I. ${ }^{1 *}$, KORENYUK L.V. ${ }^{2 *}$}

1 *Doctor of economic sciences, Professor, Head of the Department of Management of Organizations and Administration of Dniprovsk State Technical University, e-mail: korenyukp@gmail.com, ORCID ID: 0000-00018321-3199

$2 *$ Candidate of economic sciences, Associate Professor of the Department of Finance and Economic Security of the Dnieper National University named after V. Lazaryan, e-mail: lusikorenyuk@ gmail.com, ORCID ID: 0000-00033187-3288 


\section{THE INFLUENCE OF WAGES ON THE LEVEL OF UNEMPLOYMENT IN THE CONTEXT OF SOCIAL RESPONSIBILITY OF EMPLOYERS}

Object. The work is devoted to the analysis of the impact of wages on the unemployment rate in the context of social responsibility of employers and the specification of measures to reduce unemployment. Methods. To solve this scientific problem used: structural method; comparative analysis of empirical data; abstract-logical generalization. Results. The paper analyzes the impact of wages on unemployment in the context of social responsibility of employers. Based on the analysis, reserves for reducing unemployment and improving social living standards by raising the level of wages have been identified. The priority directions of its transformation into an effective tool of socio-economic development of the industrial region are indicated. Scientific novelty. In the process of analyzing the impact of wages on the unemployment rate in the context of social responsibility of employers, conclusions and proposals are made under the prism of the specifics of the Dnipropetrovsk region as an industrial region. Practical significance. Some results and conclusions of the article can be used by local authorities and local governments of industrial areas.

Keywords: salary, wage, unemployment, social, responsibility, social, labor, standards, force.

\section{REFERENCES}

1. Bohynia, D. P. (2003). Modern problems of social and labor relations, organization of wages and income regulation in Ukraine. Zbirnyk naukovykh prats. Donetsk : IEP NAN Ukrainy.1, 218. [in Ukrainian].

2. Harmyder, L. D. And Honchar L. A. (2019). Motivational factors of efficiency of the enterprise personnel. Review of transport economics and management. 1 (17), 127-132. [in Ukrainian].

3. Horilyi, A.H. (1999). Labor market economics. Ternopil: Vydavnytstvo Karp `iuka. [in Ukrainian].

4. Zaklekta, O.A. (2008). Labor migration as a condition for the development of the international labor market. Visnyk KNTEU. 4, 9-13. [in Ukrainian].

5. Iermolenko, O. A. (2014). Innovative methods of improving the human resources of public authorities. Ekonomika rozvytku, 1, 101-105. Retrieved from: http://nbuv.gov.ua/UJRN/ecro_2014_1_20. [in Ukrainian].

6. Kapitan, V. (2012). Labor migration as an aspect of the employment problem in Ukraine. Efektyvnist derzhavnoho upravlinnia, 32, 474-475. [in Ukrainian].

7. Kulytskyi, S. (2020). Ukrainian labor force in the Polish labor market at the present stage of economic development. Ukraina: podii, fakty, komentari, 15, 46-58. Retrieved from: http://nbuviap.gov.ua/images/ukraine/2020/ukr15.pdf. [in Ukrainian].

8. Krupiak, L. B. and Krupiak, I. Y. (2014). Features of structural transformations of the labor market in Ukraine. Efektyvna ekonomika, 2. Retrieved from: http://www.ekonomy.nayka.com.ua. [in Ukrainian].

9. Paziuk, O. and Ponomarova, O. (2004). Unemployment problems in Ukraine. Ukraina: aspekty pratsi, 2, 3-10. [in Ukrainian].

10. Fedoryshyna, L. M. (2015). Unemployment in Ukraine: current problems and solutions. Stalyi rozvytok ekonomiky, 4, 103-108. [in Ukrainian].

11. The State Statistics Service of Ukraine (2018). Ofitsiinyi sait Derzhavnoi sluzhby statystyky Ukrainy. Retrieved from: http://www.ukrstat.gov.ua.

Стаття надійшла до редакції: 05.06.2021

Received: 2021.06.50 